\title{
Effects of ensiling cassava peels on some fermentation characteristics and growth performance of sheep on-farm
}

\author{
R. NIAYALE, W. ADDAH* \& A.A. AYANTUNDE \\ (R.N \& W.A.: Department of Animal Science, University for Development Studies, P. O. \\ Box TL 1882, Tamale, Ghana; A.A.A.: International Livestock Research Institute, BP 9478, \\ Ouagadougou, Burkina Faso) \\ *Corresponding author's email: addweseh@yahoo.com
}

\begin{abstract}
This study determined the effect of drying or ensiling cassava peels on some conservation characteristics and growth performance of sheep. Fresh peels were either sun-dried to a $\mathrm{DM}$ of $904 \mathrm{~g} / \mathrm{kg}$ or ensiled for 45 days for determination of some chemical and microbial characteristics, and growth performance of sheep. 45 Djallonké sheep were randomly assigned to three supplementary dietary treatments (Control and dried or ensiled) and fed for 70 days. Ensiling reduced the $\mathrm{pH}$ from 5.65 in the fresh peel to 4.15 compared to 6.15 in the dried peel. Crude protein (CP) increased from $45 \pm 0.44 \mathrm{~g} / \mathrm{kg} \mathrm{DM}$ in the fresh peel to $46 \pm 0.48$ and $52 \pm 0.88 \mathrm{~g} / \mathrm{kg}$ DM in the dried and ensiled peel, respectively. Reduction in neutral detergent fibre concentration was greater by ensiling than by drying. However, a greater $(P=0.001)$ reduction in $\mathrm{HCN}$ concentration was achieved by drying than by ensiling. Moulds were greater $(P=$ $0.011)$ in the ensiled than dry peels. Average daily weight gain was higher $(P=0.031)$ for sheep offered the ensiled than the dried or Control diet. In conclusion, sun-drying was more effective at reducing $\mathrm{HCN}$ concentration whereas ensiling improved the $\mathrm{CP}$ content of cassava peels and growth performance of sheep.
\end{abstract}

Keywords: cassava peels; crop residues sheep; ensiling; growth performance; sun-drying Original scientific paper. Received 20 Aug 2019; revised 29 Oct 2020.

\section{Introduction}

The five Northern regions of Ghana characterized by a long dry season and a short raining season account for most of the animals produced in Ghana because nearly $70 \%$ of the land in these regions is suitable for livestock production (Karbo \& Bruce, 2000). However, feed shortage, especially in the dry season, is ranked first among the major challenges facing livestock production in the area (OppongAnane, 2013).

In northern Ghana, farmers rely mainly on naturally available pasture and crop residues because of the high cost of conventional feedstuff. However, a major challenge to the use of these resources is that they decline in quantity and quality during the dry season to the extent that they are unable to support optimum animal growth without supplementation (Akinfala \& Tewe, 2002; Annor \& Adongo, 1992). Therefore, feed supplementation is a good way of getting optimal performance from animals in this ecological zone, especially during the dry season. Non-conventional feedstuff such as crop residues, by-products of grain processing, and peels of roots and tuber crops can help address the problem of feed shortages during the dry season. 
Cassava is produced in almost all the ecological zones of Ghana. A survey by Seidu et al. (2012) showed that about five to six tonnes of cassava are processed in a day in each processing centre in Techiman and Wenchi in the Bono East and Bono regions of Ghana, respectively. These peels usually become an environmental nuisance in communities where they are generated in large quantities and are often left to rot or burnt (Akinfala \& Tewe, 2002).

Cassava peels are however a rich source of readily fermentable carbohydrates and can be used to improve the energy concentration of tropical grass silage diets (Onua \& Okeke, 1999). However, the utilization of cassava peels as animal feed is constrained by its high perishability (Tewe, 1992), high HCN concentration (Cardoso et al., 2005), and low protein content (Konlan et al., 2016). Hydrogen cyanide makes the peels bitter thus reducing their palatability and intake. It also interferes with the utilization of essential amino acids and the function of some enzymes (Enneking \& Wink, 2000).

Apart from the reduction in palatability, high consumption of HCN can also result in respiratory and cardiovascular weaknesses or even death (Bolarinwa et al., 2016; Obadoni \& Ochuko, 2001). Toxicity of HCN to ruminants is believed to be uncommon because of microbial detoxification of HCN in the rumen (Smith et al., 1991). This is because when cyanogenic glucoside is exposed to linamarase enzyme extraruminally during cassava processing, $\mathrm{HCN}$ is released and can be detoxified in the rumen but when unprocessed cassava peels are fed to ruminants, microbial fermentation may rather enhance $\mathrm{HCN}$ formation in the rumen thereby increasing the level of toxicity (Llewellyn, 2014).

Various methods have been used including sun-drying, soaking, grating and fermenting in an attempt to reduce cyanogenic glycoside, improve the $\mathrm{CP}$ content and increase their shelf-life. Sun-drying reduces HCN concentration by $86 \%$ whereas fermentation (ensiling) reduces it by 96\% (Tewe, 1992). Ensiling may also increase the digestibility of the peels. Ensiling improved the in situ DM degradability of dried cassava peels at $24 \mathrm{~h}$ by $3 \%$ points from $70 \%$ to $73 \%$ (Asaolu, 1988).

It is believed that the use of appropriate methods of conserving cassava peels will help to reduce feed costs and improve the efficiency of smallholder farmers. This, therefore, informed the decision to situate the study on-farm with the direct involvement of smallholder sheep farmers to enable them learn first-hand the conservation of cassava peels into animal feed. This study, therefore, sought to investigate the effects of drying or ensiling on some conservation characteristics of cassava peels and the growth performance of Djallonké sheep on-farm.

\section{Materials and Methods}

Study location

Botingli $(9.61 \mathrm{~N} 0.79 \mathrm{~W})$ is a farming community located in the guinea savannah zone of Ghana. It is bordered to the east by Savulugu, the administrative district capital of the Savulugu-Nanton $\left(9^{\circ} 24^{\prime} \mathrm{N} 0^{\circ} 28^{\prime} \mathrm{W}\right)$ district and to the South-east by Nanton. Botingli has a unimodal rainfall pattern $(950-1200 \mathrm{~mm})$ which starts in late April and ends in October. The dry season spans from November to April. Temperatures range from 33 to $39^{\circ} \mathrm{C}$ (day) to 20 to $25^{\circ} \mathrm{C}$ (night). During the harmattan, wild bushfires are rampant, destroying native pasture and crop residues left on the farm fields after harvest. Farmers keep cattle, sheep, goats and local poultry in an integrated management system with crop production. The commonest crops grown in the area include maize, groundnuts, cassava, yam and rice. 
Livestock production is mainly through the semi-intensive system of management.

Experiment I: Fermentation characteristics of cassava peels conserved by ensiling or drying Collection and processing of cassava peels

Only cassava farmers who also owned sheep were enlisted for this study. Immediately after harvesting, cassava tubers were transported home and peeled for the production of dried cassava chips. The fresh peels were collected and allowed to wilt (250-280 g/ $/ \mathrm{kg} \mathrm{DM})$ for two days. The peels were then thoroughly mixed on a clean surface to ensure uniformity and then ensiled in mini and bag silos.

For ensiling cassava peels in mini silos, approximately 2.5 to $3.0 \mathrm{~kg}$ of cassava peels were packed into each of twenty duplicate labeled mini silos $(10.4 \mathrm{~cm}$ diameter $\times 35.6$ $\mathrm{cm}$ height) by manual pressing. Each labeled silo was weighed with its cap prior to being filled and immediately after sealing. The silos were stored at ambient temperature $\left(20^{\circ} \mathrm{C}\right)$ and opened on 1, 3, 10, 15 and 45 days of ensiling as a means of monitoring the trajectory of fermentation in the bag silos. Triplicate silos were prepared and opened for each sampling day. The procedure for filling the silos involved randomly selecting one of three sets of triplicate silos $(1,2$, or 3$)$ for each sampling day and filling them with a $25-\mathrm{kg}$ lot of fresh cassava peels. Details of the mini silo experimental procedure have previously been described (Addah et al., 2012). On each opening day $(1,3,10,15$ and 45 ), the silage was sampled for determination of $\mathrm{pH}$, lactic acid, $\mathrm{HCN}$, and $\mathrm{NH}_{3}-\mathrm{N}$, and the enumeration of lactic acid bacteria, yeasts and moulds.

For growth performance experiment, one batch of the wilted peel was sun-dried for three days to a DM of $904 \mathrm{~g} / \mathrm{kg} \mathrm{DM}$ and then stored in polyethylene bags until being fed whereas the other batch was ensiled in triplicate polyethylene-lined $500-\mathrm{kg}$ capacity flexible intermediate bulk bag silos $(120 \times 90$ $\times 90 \mathrm{~cm}$; Shandong Anthente New Materials Technology Co., Ltd; Shandong, China) and kept in a thatch-roofed barn until opened after 45 days of ensiling. Prior to filling the silos, a subsample (day 0) of fresh cassava peels was also collected for the determination of some nutritional qualities of the peels prior to being conserved. On opening day (day 45), the ensiled peels were sampled for sensory evaluation and graded for their sensory quality characteristics such as colour, smell and texture, and nutritional quality such as neutral detergent fibre (NDF), acid detergent fibre (ADF), $\mathrm{NH}_{3}-\mathrm{N}$ and crude protein.

The ensiled residue was subsequently dried for three days to a DM of $940 \mathrm{~g} / \mathrm{kg}$ prior to being used to prepare two supplementary diets (Olafadehan et al., 2012). The diets were manually mixed every week and fed to sheep on-farm for 70 days. The supplementary diets consisted of either the $750 \mathrm{~g} / \mathrm{kg} \mathrm{DM}$ of the ensiled (silage diet) or dried (dried diet) cassava peels plus $25 \% \mathrm{DM}$ each of whole cotton seed. The ingredient and nutrient composition of the diets are shown in Table 1. The cotton seed was treated with $1 \%$ salt solution and rubbed vigorously between the two palms to reduce the lint and to expose the seed coat and then sun-dried ( $816 \mathrm{~g} / \mathrm{kg} \mathrm{DM})$. These were used to formulate the diet consisting of either dried or ensiled peel.

Experiment II: Growth performance

Management and feeding of experimental animals

A total of 45 sheep (4-6 months) with an initial weight of $11.9 \mathrm{~kg}(\mathrm{SD}=2.6)$ were sampled from nine communal pens at Botingli in the Savelugu-Nanton Municipal Assembly in the Northern Region of Ghana. Five sheep (three males and two females) were allocated 
to each pen, ear-tagged and dewormed with Albendazole (Hubei Guangren Pharmaceutical Technology Co. Ltd., Mainland, China) before the commencement of the experiment.

Each pen contained both experimental and non-experimental sheep. The sheep were provided with water continually. Every morning, the non-experimental flock in each pen was let out of the pen to graze on natural pasture whereas the experimental animals sampled for the study were detained in the pen and offered measured quantities of the supplementary diet from 08:30am to 12:30 pm. After $12: 30 \mathrm{pm}$, the animals were also let out to join their counterparts to graze on the field of natural pasture and the supplementary feed withdrawn. The animals returned to their pens at about 06:00pm. A Control group of animals were given similar management regimes except that salt lick was provided in each pen and sheep were let out to graze from 08:00 am to 06:00 pm and did not receive any supplementary diet. The sheep were adapted to this feeding regime for seven days prior to data collection.

The pens were made of mud and wooden rails and were owned by a group of two to four farmers. The animals were provided with water continually. Salt lick was also provided in each pen. The dried and ensiled peels were used to formulate two diets that were manually mixed every week. The diets consisted of either the $750 \mathrm{~g} / \mathrm{kg} \mathrm{DM}$ of the ensiled or dried cassava peels plus $250 \mathrm{~g} / \mathrm{kg}$ DM of whole cottonseed. The cottonseed was obtained from Wienco Cotton Industry Ltd., Tamale, Ghana. The seed was treated with $1 \%$ salt solution and rubbed vigorously between the two palms to reduce the lint and to expose the seed coat and then sun-dried (816 g/kg DM). This was then used to formulate a diet of three parts ensiled or dried peel to one-part cotton seed $(3: 1)$.
Each morning, the animals were offered measured quantities of the supplementary diet from 08:30 am to $12: 30 \mathrm{pm}$. After 12:30 pm, the animals were then let out to graze in the open field. The animals returned to the pen to sleep at about 06:30 pm. A Control group of animals were given similar management regimes except that they were let out to graze from 08:00 am to 06:00 $\mathrm{pm}$ and did not receive any supplementary diet.

\section{Growth performance}

Each animal was weighed using a scale (Avery digital scale; Avery WeighTronix, Minnesota, USA) at the beginning of the experiment and at the end of every two weeks. The initial liveweight $(\mathrm{kg})$ per animal was subtracted from the final live weight $(\mathrm{kg})$ per animal at the end of the experiment and the weight multiplied by 1000 to obtain final liveweight gain per animal in grams. This was then divided by the number of days (d) the experiment lasted to obtain the average daily weight gain in grams. The feed on offer and leftovers were weighed and sampled every 14 $d$ until the end of the experiment which lasted for $70 \mathrm{~d}$. Feed offered and leftover samples were used for determination of DM content and daily DM intake (DMI) per pen as feed offered on DM basis minus leftover feed on DM basis. Feed intake expressed as dry matter intake (DMI) was thus calculated as:

DMI $(\mathrm{g} / \mathrm{d})=[$ Fresh feed weight $(\mathrm{kg})] \times[\mathrm{DM}$ content of feed $(\mathrm{g} / \mathrm{kg})]-[$ Leftover feed $(\mathrm{kg}) \times$ DM content of leftover $(\mathrm{g} / \mathrm{kg})]$.

\section{Laboratory analyses}

Measurement of $\mathrm{pH}$

$\mathrm{pH}$ of duplicate samples of the fresh peel and those obtained on day 1, 3, 10, 15 and 45 of opening the mini silos in Experiment I was measured. About $10 \mathrm{~g}$ of the sample was 
weighed (Sartorius Gottingen, Germany) into a clean beaker. About $135 \mathrm{~mL}$ of distilled water was added and blended for 40 seconds using a kitchen blender (Kenwood, China). The blended sample was then poured into another clean beaker and a pre-calibrated $\mathrm{pH}$ meter (Sartorius, Gottingen, Germany) was used to measure the $\mathrm{pH}$ of the blended sample.

\section{Proximate and fibre analysis}

Feed samples were collected every seven days and pooled together into a single sample every $14 \mathrm{~d}(\mathrm{n}=5)$ for subsequent laboratory analyses. Proximate analysis of the diets and ingredients was carried out according to the official methods of analysis described by AOAC (2005). All analyses were done in duplicates. Neutral Detergent and ADF were determined using procedures of Van Soest et al. (1991) with the aid of an Ankom 200 fibre analyzer (Ankom Technology Corp., Fairport, NY). The concentrations of NDF or ADF were determined using the formula:

$\% \mathrm{NDF}$ or $\mathrm{ADF}=100 \times \frac{\mathrm{W}_{1} \times \mathrm{C}_{1}}{\mathrm{~W}_{2}}$

where: $\mathrm{W}_{1}=$ bag tare weight, $\mathrm{W}_{2}=$ sample weight, $\mathrm{W}_{3}=$ dried weight of bag with fibre after the extraction process, $\mathrm{C}_{1}=$ blank bag correction (running average of final oven-dried weight divided by original blank bag weight)

\section{Determination of ammonia nitrogen}

A composite portion of the fresh, dry, or ensiled cassava peel obtained after $45 \mathrm{~d}$ of ensiling in mini silos was blended and filtered through two layers of cheesecloth and the filtrate was centrifuged for $15 \mathrm{~min}$ at $10,000 \times g\left(4{ }^{\circ} \mathrm{C}\right)$. The supernatant was collected for analysis of $\mathrm{NH}_{3}-\mathrm{N}$ concentration. The supernatant $(1.6 \mathrm{~mL})$ was combined with $0.15 \mathrm{~mL}$ of $65 \%$ (wt/vol) trichloroacetic acid and analyzed by the phenolhypochlorite method described by Broderick and Kang (1980). Colorimetric calibration and quantification of $\mathrm{NH}_{3}-\mathrm{N}$ were then done on a Spectrotroquant Pharo 300 (J.P. Selecta, Spain) spectrophotometer at a wavelength of $630 \mathrm{~nm}$ at a sample concentration range of 0.00-3.00 $\mathrm{mg} / \mathrm{L}$.

\section{Hydrogen cyanide concentrations}

Total HCN (ppm) in the cassava peels was analyzed using the alkaline titration method as described by AOAC (1990) and Famurewa and Emuekele (2014). The peels (10 g) ballground to pass through No. $20 \mathrm{~mm}$ sieve was soaked in an equal volume (100 $\mathrm{ml}$ each) of a mixture of distilled water and orthophosphoric acid. The samples were each thoroughly mixed and stored at room temperature overnight. This was done to set free all bounded hydrocyanic acid. The resulting sample (mixture) was then transferred into a distillation flask and a drop of paraffin (antifoaming agent) was added. The flask was then fitted to another distillation apparatus and distilled. About $112.5 \mathrm{ml}$ of the distillate was collected in the receiving flask containing $100 \mathrm{ml}$ of distilled water and 0.25 $\mathrm{g}$ of sodium hydroxide pellets. The distillate was then transferred into a $125 \mathrm{~mL}$ volumetric flask and made up to mark with distilled water. About $4.0 \mathrm{~mL}$ of $5 \%$ potassium iodide was then added and titrated against $0.01 \mathrm{M} \mathrm{Ag}(\mathrm{NO} 3)_{2}$. End-point was indicated by faint but permanent turbidity. The total HCN content in $\mathrm{mg} / \mathrm{kg}$ was calculated as:

Total HCN content $=\frac{13.5 \times \mathrm{TV}}{\mathrm{M}} \ldots \ldots \ldots \ldots \ldots \ldots[3]$

where: $\mathrm{TV}=$ titre value, $\mathrm{M}=$ mass of sample

\section{Microbial analysis}

On each day of opening, each duplicate mini-silo was opened and subsampled and prepared for use in enumeration of lactic acid-producing bacteria (LAB) using lactobacilli MRS agar and in enumeration of 
yeasts and moulds using Sabouraud's Dextrose Agar (SDA). For enumeration of LAB, $62 \mathrm{~g}$ of the MRS agar powder was measured into a clean flask and 1L of distilled water added and dissolved by boil using a magnetic rod on a magnetic stirrer (J.P. Selecta, Spain) and then autoclaved (Microclave, J.P. Selecta, Spain) at $121^{\circ} \mathrm{C}$ for 15 minutes. The agar was then allowed to cool in a water bath $\left(50^{\circ} \mathrm{C}\right)$. The agar was poured into sterilized Petri dishes to about half-full on a laminar flow hood (Envair, Haslingden, UK) under aseptic conditions. The plates were allowed to cool and set to room temperature. A similar protocol was used for the enumeration of yeasts and moulds except that $65 \mathrm{~g}$ of the SDA was added to $1 \mathrm{~L}$ of distilled water.

About $10 \mathrm{~g}$ of the sub-sampled dried or ensiled cassava peel was weighed and added to $90 \mathrm{~mL}$ of distilled water in a ziplock bag $(17.7 \mathrm{~cm} \times 18.8 \mathrm{~cm})$ and vigorously agitated to detach the microbes from the sample. Serial dilutions of -2 to -5 were made and $1 \mu \mathrm{L}$ of each dilution $(-2,-3,-4$ and -5$)$ was used to inoculate each prepared MRS and SDA agar plates. For the MRS, the plates were placed upside-down in an incubator (Incubator- $\mathrm{Co}_{2}$, J.P. Selecta, S.A., Barcelona, Spain) at $32^{\circ} \mathrm{C}$.

Counting of bacteria or fungal colonyforming units (CFU) was done after $24 \mathrm{~h}$ for MRS media plates and $48 \mathrm{~h}$ for SDA plates using a digital colony counter (J.P. Selecta, S.A., Barcelona, Spain).

\section{Sensory evaluation of silages}

On the day of opening, 12 farmers were randomly selected and trained on the sensory evaluation criteria before administering a questionnaire to each. Sensory evaluation procedure was based on methods previously described by Jianxin (2002) and Jian et al. (2015). The farmers scored the silages for smell (1-15), colour (1-15) and texture (1-10). The silages were graded by summing the scores for each trait as excellent grade (40-31), good grade (30-21), general grade (20-11) and lowgrade $(\leq 10)$.

\section{Statistical analysis}

Data were analyzed using the PROC Mixed procedure (SAS Inst. Inc., Cary, NC). Data on microbial populations were transformed to $\log _{10}$ colony-forming units prior to statistical analysis with each mini silo as the experimental unit and the bulk storage container as the experimental unit for the dried peel. For the growth performance study, data on DMI and growth performance of sheep (body weight gain and ADG) were analyzed for the effects of ensiling as a completely randomized design with initial body weight as a covariate in the model and pen as the experimental unit. Differences in least squares means of all fixed effects were declared statistically significant at $P \leq 0.05$.

\section{Results}

Fermentation characteristics of cassava peels There was an indication of a good trajectory of fermentation as the $\mathrm{pH}$ declined rapidly (Fig. 1) from 6.2 in the unensiled peel to 4.1 in the ensiled peel and 6.1 in the dry peel after $45 \mathrm{~d}$ of ensiling (Table 1). The populations of LAB and moulds were greater $(\mathrm{P} \leq 0.04)$ in the ensiled compared to dried cassava peels (Table 1). However, the yeast population was similar $(\mathrm{P}=0.474)$ between the dried and ensiled peel. Ammonia $\mathrm{N}$ concentration was 13\% higher in the ensiled than the dried peels even though the difference was not significant $(\mathrm{P}=0.229)$. Generally, ammonia $\mathrm{N}$ concentration increased from $0.25 \mathrm{mg} / \mathrm{kg}$ in the fresh peel to $1.12 \mathrm{mg} /$ $\mathrm{kg}$ after $45 \mathrm{~d}$ of ensiling and $0.48 \mathrm{mg} / \mathrm{kg}$ after drying (Table 1). The concentration of $\mathrm{HCN}$ concentration was reduced from $27.4 \mathrm{mg} / \mathrm{kg}$ in the fresh peel to $25.0 \mathrm{mg} / \mathrm{kg}$ after ensiling and $18.0 \mathrm{mg} / \mathrm{kg}$ after drying. 
TABLE 1

Effects of conserving cassava peels by ensiling or sun-drying on some conservation characteristics after 45 d of ensiling in bag silos

\begin{tabular}{lccccc}
\hline \multirow{2}{*}{ Item } & \multicolumn{4}{c}{ Method of conservation } \\
\cline { 2 - 6 } & Fresh peel & Dried & Ensiled & SEM & P value \\
\hline $\mathrm{pH}$ & 6.1 & $6.2^{\mathrm{a}}$ & $4.2^{\mathrm{b}}$ & 0.029 & $<.0001$ \\
Ammonia N (mg/kg DM) & 0.25 & 0.48 & 1.12 & 0.365 & 0.229 \\
Hydrogen cyanide (mg/kg DM) & 27.37 & $18.0^{\mathrm{a}}$ & $25.0^{\mathrm{b}}$ & 0.145 & 0.001 \\
Lactic acid bacteria (CFU/kg DM) & nd & $5.4^{\mathrm{a}}$ & $6.4^{\mathrm{b}}$ & 0.256 & 0.014 \\
Yeasts (CFU/kg DM) & nd & 6.5 & $6.7^{\mathrm{a}}$ & 0.272 & 0.474 \\
Moulds (CFU/kg DM) & nd & $5.4^{\mathrm{a}}$ & $6.4^{\mathrm{b}}$ & 0.164 & 0.011 \\
\hline
\end{tabular}

CFU: Colony-forming units; nd: not detectable (at dilution -1).

Least square means with different superscripts within rows differ significantly $(P<0.05)$.

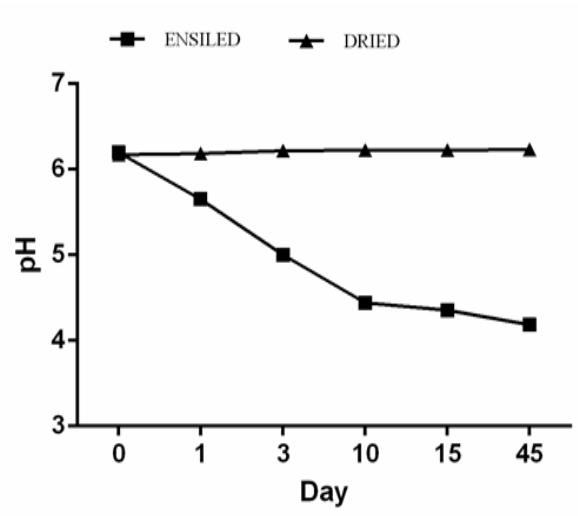

Fig. 1: Effect of conserving cassava peels by ensiling or drying on the trajectory of $\mathrm{pH}$ decline

\section{Sensory characteristics of cassava peels}

From responses collated from the questionnaires administered to selected farmers on sensory evaluation of ensiled cassava peels, the colour of the silage ranged from light brown to deep brown, the silage had a pleasant smell and a very firm texture generally rated as good quality (Table 2). No great difference in sensory characteristics among silages from the three bulk silos was observed. The sensory quality of the silage indicated that it was of good quality grade (27.7 \pm 0.72 ; Table 2$)$.
TABLE 2

Sensory characteristics of cassava peel silage after $45 d$ of ensiling in large bag silos

\begin{tabular}{llc}
\hline Item & Description & Score $^{l}$ \\
\hline Colour (1-15) & Light brown & $9.22 \pm 2.24$ \\
Smell (1-15) & Very pleasant & $10.50 \pm 2.46$ \\
Texture (1-10) & Firm & $8.00 \pm 2.10$ \\
Grade $^{2}$ & Good & $27.72 \pm 0.72$ \\
\hline
\end{tabular}

${ }^{1}$ Values are means of three large silos $(n=3)$

${ }^{2}$ The silages were graded by summing the scores for colour (1-15); texture (1-10); smell $(1-15)$ as excellent grade (40-31); good grade (30-21); general grade $(20-11)$ and low-grade $(\leq 10)$ according to Jianxin (2002) and Jian et al., (2015).

Proximate composition of cassava peels and diets

The NDF concentration of cassava peels decreased from $448 \pm 11.0 \mathrm{~g} / \mathrm{kg} \mathrm{DM}$ in the fresh peel to $418 \pm 15.1 \mathrm{~g} / \mathrm{kg}$ DM and $364.1 \pm 7.6 \mathrm{~g} / \mathrm{kg}$ $\mathrm{DM}$ in the dried and ensiled peel, respectively. On the contrary, ADF increased from $133 \pm 1.2$ $\mathrm{g} / \mathrm{kg} \mathrm{DM}$ in the fresh to $139 \pm 0.65 \mathrm{~g} / \mathrm{kg} \mathrm{DM}$ and $190 \pm 1.5 \mathrm{~g} / \mathrm{kg}$ DM in the dried and ensiled peels respectively. Ensiling also increased the $\mathrm{CP}$ concentration from $45 \pm 0.44 \mathrm{~g} / \mathrm{kg} \mathrm{DM}$ in the fresh peel to $46 \pm 0.48 \mathrm{~g} / \mathrm{kg}$ DM in the dried peel and $52 \pm 0.88 \mathrm{~g} / \mathrm{kg}$ DM in the ensiled peel. The trend of the CP and NDF concentrations of the ensiled and dried peel was consistent with 
the concentration of these constituents in the respective diets (Table 3 ).

TABLE 3

Nutrient composition (mean \pm SEM) of dried or ensiled cassava peels and diet

\begin{tabular}{lcccccc}
\hline \multirow{2}{*}{ Item $(\mathrm{g} / \mathrm{kg}$ DM) } & \multicolumn{3}{c}{${ }^{1}$ Cassava Peels } & & \multicolumn{2}{c}{${ }^{2}$ Diet } \\
\cline { 2 - 3 } \cline { 6 - 7 } & Fresh & Dried & Ensiled & & Dried & Ensiled \\
\hline Dry matter & $945 \pm 5.6$ & $941 \pm 7.6$ & $945 \pm 6.7$ & & $944 \pm 8.5$ & $950 \pm 6.1$ \\
Crude protein & $45 \pm 0.44$ & $46 \pm 0.48$ & $52 \pm 0.88$ & & $103 \pm 5.0$ & $126 \pm 4.2$ \\
Ether extract & - & - & - & & $42 \pm 4.8$ & $74 \pm 5.5$ \\
NFE & - & - & - & & $646 \pm 9.4$ & $559 \pm 9.6$ \\
Ash & $43.6 \pm 1.3$ & $46 \pm 1.8$ & $45.3 \pm 0.1$ & & $44 \pm 1.5$ & $44 \pm 2.4$ \\
NDF & $448 \pm 11.0$ & $418 \pm 15.1$ & $364.1 \pm 7.6$ & & $463 \pm 16.5$ & $325 \pm 4.5$ \\
ADF & $133 \pm 1.2$ & $139 \pm 0.65$ & $190 \pm 1.5$ & & $216 \pm 7.1$ & $232 \pm 15.4$ \\
NH $-\mathrm{N}(\mathrm{mg} / \mathrm{kg} \mathrm{DM})$ & 0.25 & $0.48 \pm 0.01$ & $1.12 \pm 0.51$ & & $0.58 \pm 0.01$ & $0.35 \pm 0.06$ \\
${ }^{3} \mathrm{ME}(\mathrm{MJ} / \mathrm{kg} \mathrm{DM})$ & - & - & - & & 12.5 & 12.7 \\
\hline
\end{tabular}

${ }^{1}$ Cassava peels were either analyzed as fresh, dried (6 d) or ensiled (45 d) in 3 large polyethylene-lined bag silos ${ }^{2}$ Diet contained cassava peels (dried or ensiled) and whole cotton seed in a ratio of 3:1.

${ }^{3}$ ME: Metabolizable Energy (MJ/kg DM; Pauzenga, 1985).

\section{Animal growth performance}

There was no significant difference $(P$ $=0.637)$ in the initial weight of sheep among the three treatments. There was a significant difference between animals fed the peel-based diets (ensiled or dried) compared to those on the Control group in terms of total weight gained $(P=0.040)$ and final weight attained $(P=0.028)$. However, the growth performance of sheep fed the ensiled or dried cassava peelbased diet did not differ significantly $(P>0.05)$. Dry matter intake of the diets did not differ $(P$ $=0.436$ ) between sheep receiving the dried or ensiled supplementary diet even though those in the ensiled group had higher numerical values. Supplementation of sheep with ensiled and dried cassava peels however resulted in higher $(P=0.031)$ average daily weight gain compared to the Control. Ensiling also resulted in higher daily gain than drying even though the difference between the ensiled and the dried were not significant $(P=0.293)$. The growth pattern of the sheep showed that the growth performance of the sheep in the Control group was consistently inferior to those offered the dry and ensiled peels throughout the 70-day feeding period (Fig. 3).

TABLE 4

DMI and growth performance of sheep without feed supplementation or supplemented with dried or ensiled cassava peels for $70 \mathrm{~d}$

\begin{tabular}{llllll}
\hline Item & Dried & Ensiled & Control & SEM & P value \\
\hline Initial weight $(\mathrm{kg})$ & 12.6 & 11.9 & 11.3 & 1.06 & 0.637 \\
Final weight $(\mathrm{kg})$ & $18.0^{\mathrm{a}}$ & $18.7^{\mathrm{a}}$ & $16.0^{\mathrm{b}}$ & 0.55 & 0.040 \\
Weight gain $(\mathrm{kg})$ & $6.1^{\mathrm{a}}$ & $6.9^{\mathrm{a}}$ & $4.0^{\mathrm{b}}$ & 0.53 & 0.028 \\
DM intake $(\mathrm{g} / \mathrm{d})$ & 180 & 230 & - & 0.04 & 0.436 \\
\hline
\end{tabular}

SEM: Pooled standard error of least square means $(n=6)$ 


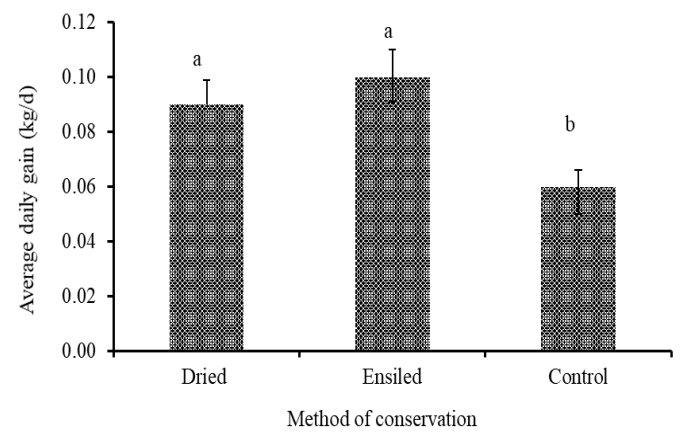

Fig. 2: Effects of conserving cassava peels by ensiling or drying on average daily weight gain of sheep

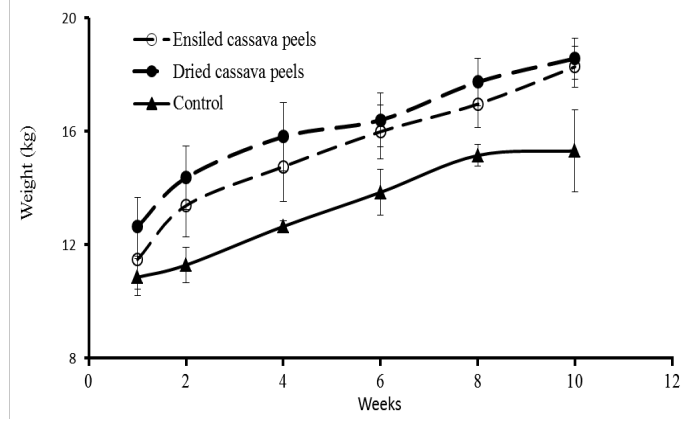

Fig. 3: Effects of conserving cassava peels by ensiling or drying on growth performance of sheep after $70 \mathrm{~d}$ of supplementation.

\section{Discussion}

The reduction in the concentration of NDF during ensilage is suggestive of the solubility of NDF in cassava peels. Hemicellulose and cellulose constitute the digestible fractions of NDF. Hemicellulose contains arabinoxylans and glucuronoarabinoxylans. These can be hydrolysed by the pentose-phosphate pathway of fermentation by heterolactic lactic acid bacteria during ensiling resulting in a reduction in NDF. In previous studies, ensiling cassava peels reduced NDF by $25 \%$ compared to sun drying (Olafadehan et al., 2012).

As expected, $\mathrm{pH}$ of the ensiled peel was lower than the dried peel and was consistent with the high concentration of lactic acid and the increase in the population of lactic acid-producing bacteria. Lactic acid bacteria are the main micro-organism responsible for the fermentation of sugars to lactic acid. Even though Kung and Shaver (2002) suggested that tropical silages should have a $\mathrm{pH}$ of 4.3-4.7 to be graded as good silage, this benchmark cannot be directly applied to tropical crop residues. At harvest, tropical forages especially crop residues have lower water-soluble carbohydrates and high cell wall concentration. These conditions together with higher environmental temperatures in the tropics give the less desirable bacilli a competitive advantage over lactic acid-producing bacteria which are rather more efficient converters of water-soluble carbohydrates to lactic acid (Oude Elferink et al., 2000). A minimum $\mathrm{pH}$ of 4.4 has been used as a benchmark for classifying cassava peel silage as being good (Asaolu, 1988) but Meneses et al. (2007) recommended a $\mathrm{pH}$ of 3.5-5.5 as an acceptable threshold for good silage made from crop byproducts.

A $\mathrm{pH}$ of 4.1 observed in this study was associated with good sensory quality characteristics including light-brown colour and a pleasant odour (Table 2), an indication of the less proliferation of saccharolytic spoilage organisms during ensilage. Figure 1 indicates a faster rate of $\mathrm{pH}$ decline during fermentation. The rate of $\mathrm{pH}$ decline influences the quality of the silage. A slower rate of decline provides more time for the growth of undesirable enterobacteria that grow well at a $\mathrm{pH}$ greater than 5 (Schroeder, 2004). The concentration of $\mathrm{NH}_{3}-\mathrm{N}$ was $13 \%$ higher in the ensiled peel compared to the dried peel even though the difference was not significant. Ammonia N is a by-product of proteolytic degradation of protein and is undesirable in the production of good quality silage. The concentration 
of $\mathrm{NH}_{3}-\mathrm{N}$ was higher in the ensiled than dried peel but a reverse trend was the case in the respective diets; the dried peel diet had higher $\mathrm{NH}_{3}-\mathrm{N}$ concentration than the ensiled peel $(0.58$ vs. $0.35 \mathrm{mg} / \mathrm{kg})$. Though this may be puzzling, the drastic increase in $\mathrm{NH}_{3}-\mathrm{N}$ concentration in the dried peel diet could be attributed to the proteolytic activity of yeasts and moulds during storage and feeding. In this study, diets were sampled every $7 \mathrm{~d}$ for chemical analysis until the end of the study. Such secondary fermentation in cassava peels has been described as "dry fermentation" and is reported to occur when the peels are improperly stored prior to use (Tewe, 1992). We, therefore, suspect that the dry peels in our study was not properly stored.

The number of moulds was increased by ensiling than drying. The principal factor affecting aerobic deterioration of silage is the population of yeasts that initiate the deterioration. A population threshold of $5 \mathrm{log}$ $\mathrm{CFU} / \mathrm{g} \mathrm{DM}$ has been established for silage to undergo deterioration (Woolford, 1990). Our values were above this threshold meaning our material may have been undergoing deterioration. The ensiled peel generally smelled pleasant, had firm texture with a light brown to brown colour which agrees with a study by Asaolu (1988) who reported that good quality silage is produced when cassava peels silage is light brown in colour, firm in texture with a pleasant odour and a $\mathrm{pH}$ of 4.4. The colour of the silage is close to the colour of the original fresh peels hence the silage is considered to be of good quality. Silage should be preserved and be close to the colour of the original fresh forage for it to be considered as good quality silage (Oduguwa et al., 2007; Liu \& Guo, 2002).

The population of moulds was increased by ensiling than drying. The increased population of these microbial cells possibly accounted for the higher $\mathrm{CP}$ in the ensiled compared to dried peel. The sensory characteristics and rapid decline in $\mathrm{pH}$ of the ensiled peel indicated a good trajectory of fermentation. Putrefied silage has a dark colour, unrecognizable plant parts (bad texture) and a rancid and nauseous smell (Jianxin, 2002).

A further indication that the silage was well-fermented is the fact that ensiling did not depress intake of the supplementary diet. A comparison between silage and hay conserved from forage of the same maturity suggest that voluntary intake of silage is usually about $17 \%$ lower than hay (Thiago et al., 1992). This suggests that the end products of the ensiling process may limit intake. The reduction in intake is principally influenced by the endproducts of fermentation via their pre-ingestive effects on palatability (Buchanan-Smith, 1990) or post-ingestive effects on ruminal VFA concentrations (Oba \& Allen, 2003).

Hydrogen cyanide imposes bitterness on the peel that may reduce palatability. The intake of the diet containing the ensiled peel was $28 \%$ greater than that containing the dried peel even though the difference was not significant. The HCN concentration of the dried peel was lower than that of the ensiled peel but ADG of sheep supplemented with the ensiled peel were superior to those supplemented with the dried peel and those on the Control. In general, the depression in growth performance of animals fed cassava-based diets has been attributed to the interference of functions of metalcontaining enzyme systems responsible for cell respiration and function by $\mathrm{HCN}$ in cassavabased diets. On contrary, however, in pigs, $\mathrm{N}$ digestibility and retention have been shown to be greater for pigs fed ensiled cassava leaves diet than for those fed dry leaves diet despite the latter being higher in $\mathrm{HCN}$ concentration (Phuc et al., 1996). Tweyongyere \& Katongole (2002) examined three methods of $\mathrm{HCN}$ 
detoxification of cassava peels; sun-drying, fermentation and soaking. They concluded that sun-drying was the most effective method and resulted in the most rapid reduction of $\mathrm{HCN}$; more than $82 \%$ reduction in $48 \mathrm{~h}$.

Sun-drying cassava leaves reduced $\mathrm{HCN}$ content to $22.5 \mathrm{mg} / \mathrm{kg}$ compared to 147 $\mathrm{mg} / \mathrm{kg}$ for the ensiled material (Phuc et al., 1996). Phuc et al. (1996) therefore concluded that drying may be more effective at removing $\mathrm{HCN}$ than ensiling. Other studies however showed that ensiling reduced free $\mathrm{HCN}$ of the peel by $36 \%$ (Gomez \& Valdivieso, 1988) to 98\% (Tewe, 1992) compared to a reduction of $82 \%$ (Tweyongyere \& Katongole, 2002) to $85 \%$ (Gomez et al., 1984) by sun-drying. In these latter studies, the greater reduction due to ensiling was generally attributed to the combined effect of lower $\mathrm{pH}(<4.4)$ and intense heat generated in the silo during ensiling. Slower rate of sun-drying (1-3 d) in the rainy season removes bound $\mathrm{HCN}$ more effectively than other artificial methods of detoxifying cassava peels because apart from the slow generation of heat during sun-drying, "dry fermentation" occurs with cassava peels conserved by sun-drying. This phenomenon further reduces the $\mathrm{HCN}$ concentration due to enhanced hydrolysis of cyanogenic glucosides by linamarase caused by slow heating during sun-drying (Famurewa and Emuekele, 2014; Lukuyu et al., 2014).

It has been suggested that improvements in growth performance of sheep fed ensiled compared to dried cassava peels diets could be due to the improvement in $\mathrm{CP}$ content and rumen degradability (Asaolu, 1988) rather than reduction in HCN. Indeed, the HCN concentration in this study was not beyond the level of $30 \mathrm{mg} / \mathrm{kg}$ recommended to cause depression in growth performance or death (Tweyongyere and Katongole, 2002). The increased populations of bacteria and fungi during fermentation have been reported to increase the microbial protein of the silage (Oboh, 2006). This could account for the higher concentration of $\mathrm{CP}$ observed in the silage and silage diets and subsequently, the improved growth performance of sheep fed the ensiled cassava peels diet. The ADG of sheep supplemented with the dried and ensiled cassava peels in the present study compares favourably with those of Asaolu (1988) who fed two groups of sheep with diets containing $80 \%$ each of dried and ensiled cassava peels. In that study, ADG for sheep fed $80 \%$ ensiled cassava peels was $0.08 \mathrm{~kg} / \mathrm{d}$ compared to 0.06 $\mathrm{kg} / \mathrm{d}$ for the dried peel.

The poorest growth performance of sheep in the Control was expected. The quality and quantity of feed resources in the northern parts of Ghana decline greatly during the dry season often necessitating supplementation to avoid weight loss.

\section{Conclusion}

Conserving cassava peels by sun-drying was more effective at reducing $\mathrm{HCN}$ concentration compared to ensiling but the nutritional quality of the peel, in terms of CP content, was improved by ensiling than by sun-drying. This study further indicates that supplementation of sheep with the ensiled peel improves the growth performance of sheep on-farm than supplementation with the dried peel or not providing supplementary feed at all during the dry season. This study therefore recommends conservation of cassava by ensiling in the wet season and sun-drying in the dry season.

\section{Acknowledgment}

We are grateful to USAID (under the Africa RISING project) and its partners International Livestock Research Institute (ILRI) and International Institute of Tropical Agriculture (IITA) for their financial support in the research 
work. We also appreciate people of Botingli community especially those who were directly involved in the study for their support during the data collection.

\section{REFERENCES}

Addah, W., Baah, J., Okine, E. K. \& McAllister, T. A. (2012) A third-generation esterase inoculant alters fermentation pattern and improves aerobic stability of barley silage and the efficiency of body weight gain of growing feedlot cattle. Journal of Animal Science 90, $1541-15452$.

Akinfala, E. O. \& Tewe, O. O. (2002) Utilization of varying levels of palm kernel cake and cassava peels by growing pig. Tropical Animal Production Investment 5, 87 - 93.

Annor, S. Y. \& Adongo, S. A. (1992) The effect of treatment of crop residues with urea on feed intake and live weight performance of West African dwarf sheep in the dry season: The role of women. In: Amanfor, W. and Koney, E. B. M. (eds.). Proceedings of the West African Commonwealth Association/Ghana veterinary Medical Association Conference, Accra International Conference Centre, Ghana. September 7-12. p. 143.

AOAC. (1990) Official method of analysis Association of Official Analytical chemist. 15 $5^{\text {th }}$ edition. Washington D.C, USA.

AOAC. (2005) Official methods of analysis. $18^{\text {th }}$ Edition. Association of official analytical chemists Arlington, VA.

Asaolu, V. O. (1988) Utilization of cassava peels and Gliricidia sepium in the diet of the West African Dwarf sheep. MPhil. thesis. Obafemi Awolowo University, Nigeria.

Awuma, K. S. (2012) Description and diagnosis of crop-livestock systems in Ghana. In: Proceeding of Regional Workshop on Sustainable Intensification of Crop-Livestock Systems in Ghana for Increased Farm Productivity and Food/Nutrition Security, 27 -28 August, 2012. $74-86$.
Bolarinwa, I. F., Oke, M. O., Olaniyan, S. A. \& Ajala, A. S. (2016) A review of cyanogenic glycosides in edible plants. In: Soloneski, S. and Larramendy, M. (eds.). Toxicology: new aspects to this scientific conundrum. In TechOpen. Janeza Trdine, Rijeka, Croatia. p.218.

Broderick, G. A. \& Kang, J. H. (1980) Automated simultaneous determination of ammonia and total amino acids in ruminal fluid and in vitro media. Journal of. Dairy Science 63, 64 - 75.

Buchanan-Smith, J. G. (1990) An investigation into palatability as a factor responsible for reduced intake of silage by sheep. Animal Production 50, $253-260$.

Cardoso, A. P., Mirione, E., Ernesto, M., Massaza, F., Cliff, J., Haque, M. R., \& Bradbury, J. H. (2005) Processing of cassava roots to remove cyanogens. Journal of Food and Compositional Analysis 18, 451 - 460.

Ekundayo, J. A. (1980) Fungal Biotechnology. Smith, J. E., Berry, D. R. and Kristiasen, B. (eds.). London: Academic Press. 244 - 270.

Enneking, D. \& Wink, M. (2000) Towards elimination of anti-nutritional factors in grain legumes. In: Knight, R. (ed.). Linking research and marketing opportunities in the $21^{\text {st }}$ century. Kluwer Academic Publishers, Dordrecht, the Netherlands. $671-683$.

Famurewa, J. A. V. \& Emuekele, P. O. (2014) Cyanide reduction pattern of cassava (Mannihot esculenta) as affected by variety and air velocity using fluidized bed dryer. African Journal of Food Science 5, 75 - 80.

Gomez, G. \& Valdivieso, M. (1988) The effects of ensiling whole root chips on cyanide elimination. Nutrition Reports International 37, $1161-1166$.

Gomez, G., Valdivieso, M., De la Cuesta, D. \& Salcedo, T. S. (1984) Effect of variety and plant age on the cyanide content of whole root cassava chips and its reduction by sun drying. Animal Feed Science Technology 11, 57 - 65. 
Heuzé, H., Tran, G., Bastianelli, D., Archimède, H. \& Lebas, F. (2012) Cassava peels, cassava pomace and other cassava tubers by-products. Feedipedia.org and Tables Régions Chaudes. A project by INRA, CIRAD and AFZ with the support of FAO. http://www.feedipedia.org/ node $/ 526$.

Jian, G., Cuijun, Y. \& Guihe, L. (2015) Analysis of wilting and mixed silage effect on naked oats (Avena nuda) and alfalfa (Medicago sativa). International Journal of Agricultural Biology $17,761-766$.

Jianxin, L. (2002) Ensiling crop residues. In: Guo, T., Manuel, D. S. and \& Guo, P. Y. (eds.). Animal production based on crop residues Chinese experiences. Food and Agriculture Organization of the United Nations. $82-103$.

Karbo, N. \& Bruce, J. (2000) The contribution of livestock production to food security in Northern Ghana. CIDA (Canadian International Development Agency) food security programme. A report submitted to CIDA by the Animal Research Institute of the Council for Scientific and Industrial Research, Tamale, Ghana. 3-11.

Konlan, S. P., Ayantunde, A. A., Addah, W., Dei, H. K., \& Karbo, N. (2016) Emerging feed markets for ruminant production in Northern Ghana. In: Abdul-Rahman, I. I., Ansah, T. Addah, W. and Acquah B. (eds.). Proceeding of the Animal Science Association. International Conference Centre, University for Development Studies, Tamale. August $3-6^{\text {th }}, 2016.322-336$.

Kung, L. \& Shaver, R. (2002) Interpretation and use of silage fermentation analyses reports. Department of Animal and Food Science, University of Delaware Newark, Delaware. Focus on Forage 3 (13), 1 - 5.

Liu, J. \& Guo, J. (2002) Ensiling crop residues. FAO. Animal Production and Health. Paper 149. FAO, Rome.
Liu, J. \& Guo, J. (2002) Ensiling crop residues. FAO. Animal Production and Health. Paper 149. FAO, Rome.

Llewellyn, D. (2014) Prussic acid poisoning in livestock. Washinton State University Extension Facts Sheet FS129E. 1-3. Available at: https://s3.wp.wsu.edu/uploads/ sites/2071/2014/01/Prussic-Acid-Poisoningin-Livestock.pdf. November 28, 2019.

Lukuyu, B., Okike, I., Duncan, A., Beveridge, M. \& Blümmel, M. (2014) Use of cassava in livestock and aquaculture feeding programs. ILRI. Nairobi, Kenya. International Livestock Research Institute. Discussion Paper 25.

Meneses, M. D., Megias J., Madrid, A., MartinezTeruel, F., Hernandez, J. \& Oliva, J. (2007) Evaluation of the phytosanitary, fermentative and nutritive characteristics of the silage made from crude artichoke (Cynara scolymus L.) by-product feeding for ruminants. Small Ruminant Research 70, 292 - 296.

Milford, R. \& Haydock, K. P. H. (1965) The nutritive value of protein in subtropical pasture species grown in south-east Queensland. Australian Journal of Experimental Agriculture and Animal Husbandry 5,13 - 17.

Muck, R. E. (1989) Initial bacterial numbers on Lucerne prior to ensiling. Grass and Forage Science 44, 19-25.

Oba, M. \& Allen, M. S. (2003) Intra-ruminal infusion of propionate alters feeding behavior and decreases energy intake of lactating dairy cows. Journal of Nutrition 133, 1094 - 1099.

Obadoni, B. O. \& Ochuko, P. O. (2001) Phytochemical studies and comparative efficacy of the crude extract of some homeostatic plants in Edo and Delta states of Nigeria. Global Journal of pure and Applied Science 18, 23 208.

Oboh, G. (2002) Nutritional, toxicological and byproducts utilization potentials of microfungi fermented cassava (Manihot esculenta, 
Crantz) tuber roots. Akure, Federal University of Technology, Thesis (PhD).

Oduguwa, B. O., Jolaosho, A. O. \& Ayankoso, M. T. (2007) Effect of ensiled on physical properties, chemical composition and mineral contents of guinea grass and cassava tops silage. Nigerian Journal of Animal Production 34, 100 - 106.

Olafadehan, O.A., Olafadehan, O.O., Obun, C. O., Yusuf, A.M., Adewumi, M.K., Omotugba, S.K. \&, Daniel, N. E. (2012) Influence of processing cassava peels on the hydrogen cyanide concentration, nutritive value and performance of growing rabbits. Tropical animal health and production 44, 285 - 291.

Onua, E. C. \& Okeke, G. C. (1999) Replacement value of processed cassava peel for maize silage in cattle diet. Journal of Sustainable Agricultural and Environment 1, 38 - 43.

Onyimonyi, A. E. \& Ugwu, S. O. C. (2007) Bioeconomic indices of broiler chicks fed varying ratios of cassava peel. International Journal of Poultry Science 6, 318 - 321.

Oppong-Anane, K. (2013) Cassava as animal feed in Ghana: Past, present and future. Berhanu, B., Cheikh, L. and Harinder, P.S. M. (eds.). FAO, Accra, Ghana. p. 44.

Ososanya, T. O. \& Olorunnisomo, O. A. (2015) Silage characteristics and preference of sheep for wet brewer's grain ensiled with maize cob. Livestock Research for Rural Development 27 (12).

Oude Elferink, S. J. W. H., Driehuis, F., Gottschal, J. C. \& Spoelstra, S. F. (2000). Silage fermentation processes and their manipulation. In: L., t'Mannetje (Ed.). Silage making in the tropics with particular emphasis on smallholders. Proc. FAO Electronic Conference on Tropical Silage. 1 Sept. 15 Dec. 1999. FAO Plant Production and Protection Paper 161, Food and Agricultural Organization of the United Nations, Rome, Italy.
Pauzenga, U. (1985) Feeding parent stock. In: Zootecnica International. $22-24$.

Phuc, B. H. N., Ogle, R. B., Lindberg, J. E. \& Preston, T. R. (1996) The nutritive value of sun-dried and ensiled cassava leaves for growing pigs. Livestock Research for Rural Development. Volume 8, Article \#30. Retrieved Dec. 21, 2016, from http://www. lrrd.org/lrrd8/3/phuc83.htm.

Schroeder, J. W. (2004) Silage fermentation and preservation. NDSU Extension Service. North Dakota State University, Fargo, North Dakota. $58-105$.

Seidu, J. M., Kwenin, W. J., Tevor, N., Ahiadorme, W. J. \& Mahama, A. A. (2012) Cassava peel and the environment. A case study of cassava processing centres in Ghana. Ghana Journal of Agricultural Science 45, 41 - 47.

Smith, O. B., Idowu, O. A., Asaolu, V. O. \& Odunlami, O. (1991). Comparative rumen degradability of forages, browse, crop residues and agricultural by-products. Livestock Research for Rural Development 3 (2).

Sogunle, O. M., Fanimo, A. O., Abiola, S. S. \& Bamgbose, A. M. (2009). Performance of growing pullets fed cassava peel meal diet supplemented with cashew nut reject meal, Archives Zootechnology 58, 23 - 31.

Tewe, O.O. (1992) Detoxification of cassava products and effects of residual toxins on consuming animals. In. Roots, tubers, plantains and bananas in animal feeding. Proceedings of the FAO Expert Consultation held in CIAT, Cali, Colombia 21-25 January 1991. Machin, D. \& Nyvold, S. (eds.). FAO Animal Production and Health Paper No. 95.

Thiago, L. R. L., Gill, M. \& Dhanoa, M. S. (1992) Studies of method of conserving grass herbage and frequency of feeding in cattle. Voluntary feed intake, digestion and rate of passage. British Journal Nutrition 67, 305 - 318. 
Tweyongyere, R. \& Katongole, I. (2002) Cyanogenic potential of cassava peels and their detoxification for utilization as livestock feed. Veterinary and Human Toxicology 4, $366-$ 369.

Ubalua, A.O. (2007) Cassava wastes: treatment options and value addition alternatives. African Journal of Biotechnology 6, 2065 2073.
Van Soest, P. J., Robertson, J. B. \& Lewis, B. A. (1991) Method for dietary fibre, neutral detergent fibre and non-starch poly saccharide in relation to animal nutrition. Journal of Dairy Science 74, 3583 - 3597.

Woolford, M. K. (1990) The detrimental effects of air on silage. Journal of Applied Microbiology 68, $101-116$. 